\title{
THE DEVELOPMENT OF SKILL WORKBOOK OF STRATEGIC MANAGEMENT COURSE FOR STUDENTS OF MANAGEMENT SCIENCE FACULTY, THEPSATRI RAJABHAT UNIVERSITY
}

\author{
Kulchalee Puangpejara \\ koon511@ hotmail.com \\ Thepsatri Rajabhat University, \\ 321 Narai Maharat Road, Mueang District, Lop Buri Province, 15000 Thailand
}

\begin{abstract}
The objectives of this research were to: (1) develop the skill workbook on environmental analysis and generating strategies of strategic management course for students of Faculty of Management Science, Thepsatri Rajabhat University in order to meet the standard criterion of 80/80; and (2) compare the students' learning achievement before and after using the skill workbook. The samples, selected by purposive sampling, were 35 students of accountant major of Faculty of Management Science, Thepsatri Rajabhat University. The research instruments included: 1) a skill workbook on the environmental analysis and generating strategies, and 2) a learning achievement test.The data were systematically analyzed by descriptive statistics (percentage :\% ; mean: $\mathrm{M}$; and standard deviation : S.D.) and inferential statistics (t-test dependent). The research findings were as follows: 1) the efficiency of the skill workbook yielded the value at 83.84/81.32, which was higher than the standard criterion of $80 / 80$. That was to say, the students' knowledge on strategic management course attained by using skill workbook as teaching aid was improved, and 2) the students' learning achievement after using the aforementioned workbook was higher than that before using it because posttest mean score $(\mathrm{M}=16.31)$ was higher than pretest mean score $(M=8.37)$ with the systematically significant difference at the $p=.05$ level.
\end{abstract}

Keywords: Learning Achievement, Skill Workbook, Environmental Analysis, Strategic Management.

\section{INTRODUCTION}

Thai National Education Act of B.E. 2542 (1999) guides teachers that education shall be based on the principle that all learners are capable of learning and self-development. The teaching - learning process shall aim at enabling the learners to develop themselves at their own pace and to the best of their potentiality. In organizing the learning process, teachers shall: provide substance and arrange activities in the line with the learners' interests and aptitudes, bearing in mind individual differences; provide training in thinking process; organize activities for learners to draw from authentic experience such as drill in practical work for complete mastery, enable learners to think critically and acquire the reading habit and continuous thirst for knowledge; and enable individuals to learn at all times and in all place 
and focus on teaching students by practicing more than listening lecture (Office of the National Education Commission, 1999).

Strategic management is a core course for undergraduate business management programs of Faculty of Management Science, Thepsatri Rajabhat University. The purpose of this course is to enable students to analyze the environment both internal and external or to analyze the SWOT using for solving management decision problems that may arise in any organization be it a firm, a not-for-profit organization when it seeks to achieve some goal subject to internal and external environment. Strategic management focuses on analyzing both internal and external environments and assessing the long-term situation of the organization, thus it is the important tool for administrators.

Based on researcher's experience, it was found that students might not understand the content of SWOT analysis: strengths, weaknesses, opportunities, and threats and generating alternative strategies. To solve this problem before teaching and learning, researcher conducted the survey by questionnaire. The survey found that students offered the option of solving the problem by asking researcher to develop a skill workbook to be used as a teaching aid, which was consistent with the previous study on Reading workbooks : Teacher beliefs and usage (Macfarlane,1984) that the teachers believe that workbooks are an important instructional aid in the teaching of reading.

From the aforementioned discussion, it is clear that there is a need to develop the skill workbook on the environmental analysis and generating strategies of strategic management course for students of Faculty of Management Science, Thepsatri Rajabhat University. The results of this research will be useful guidelines.

\section{RESEARCH OBJECTIVES}

The objectives of this study were twofold:

1. To develop the skill workbook on the environmental analysis and generating strategies of strategic management course to meet the efficiency criterion of $80 / 80(\%)$.

2. To compare the students' learning achievement between before and after using the skill workbook on the environmental analysis and generating strategies of strategic management course.

\section{RESEARCH HYPOTHESES}

The hypotheses of this study were as follows:

1. The efficiency of the skill workbook on environmental analysis and generating strategies meets the standard criterion of $80 / 80$.

2. The students' learning achievement after using the skill workbook on the environmental analysis and generating strategies is higher than that before using it $(\mathrm{p} \leq .05)$.

\section{SCOPE OF RESEARCH}

1. Scope of variables:

1.1 Independent variable was the skill workbook on the environmental analysis and generating strategies. 
1.2 Dependent variable was the students' learning achievement.

2. Scope of contents:

2.1 Internal and external environment analysis or SWOT analysis

2.2 Generating alternative strategies using TOWS matrix

3. Scope of the time

This research was conducted in the second semester of the academic year 2017, two hours per week together with practice.

\section{REVIEW OF THE LITERATURE}

In this section the literature on strategy, strategic management, SWOT analysis, and generating strategies were reviewed.

\section{Strategy}

Strategy is a plan of action designed to achieve overall aim of an organization.

According to Marcus (2011, p.3) strategy is the moves companies can make better achieve sustained competitive advantage.

Minzberg \& Quinn (1991, p.5) defines that strategy is a plan that comprises main objectives, policies and actions of organization to provide it focusing on the desired image.

Dess \& Miller (1993, p.5) divided strategies into two categories: intended strategies and realized strategies.

\section{Levels of Strategy}

There are three primary levels in organizations and are classified according to the scope of what they are intended to accomplish. The three levels are grand business, and functional strategies (Rue \& Byars, 2000, p.143)

- Grand Strategies: Strategies that address which businesses will be allocated among those businesses are referred to as grand strategies. They are established at the highest levels in the organizations. Grand strategies are the overall direction of the organizations, specifically tied to mission statements, and generally formulated by top managers. Four basic grand strategy types include: growth, stability, retrenchment, and combination.

- Business Strategies: The second primary level of strategy formulation focuses on how to compete in a given business. Narrower in scope than a corporate strategy, a business strategy generally applies to a single business unit. Most of these strategies can be classified as overall cost leadership, differentiation etc.

- Functional Strategies: The functional strategies are primary level of strategy. Functional strategies are the activities of the different functional areas of the business production, finance, marketing, personnel, and the like. Functional strategies are in effect for a relatively short period, often one year or less. 


\section{Strategic Management}

Strategic management is that set of managerial decisions and actions that determines the long-run performance of an organization. It entails all of the basic management functions. (Robbins \& Coulter, 2002, p.198)

Pearce \& Robinson (2013, p.3) stated that strategic management is the set of decisions and actions that result in the formulation and implementation of plans designed to attain a company's goals.

As noted by Wheelen \& Hunger (2012, p.53) strategic management is the set of decisions and action including: environmental scanning, strategic formulation, strategy implementation, and evaluation and control.

According to Thompson \& Strickland (1999, pp.3-4) defines that strategic management as five steps of the process of task: forming a strategic vision, setting goals, crafting a strategy, implementing and to executing the chosen strategy and evaluating performance and initiating corrective adjustment.

\section{The Strategic Management Process}

The management process is an eight- step process that encompasses strategic planning, implementation, and evaluation. Let's examine in brief the eight steps in the strategic management process (Robbins \& Coulter, 2002, pp.200-205).

Step 1: Identify the organization's current mission, objectives and strategies

Every organization needs a mission which forces managers to identify the scope of its products or services.

Step 2: Analyze the environment the scope of its products

Analyzing environment is a major step in the strategy process because a successful strategy will accord the environment.

Step 3: Identify opportunities and threats

Opportunities are positive trends in external environmental factors; threats are negative trends.

Step 4: Analyze the organization's resources and capabilities

The internal analysis provides critical information of an organization's on resources and capabilities.

Step 5: Identify strengths and weaknesses

Strengths are any activities the organization does well whereas weaknesses are the activities the organization does not do well.

Step 6: Formulate strategies

Strategies need to be established for the corporate, business and functional levels of organization. Successful managers will choose strategies that give their organizations the most favorable competitive edge.

Step 7: Implement strategies

After strategies are formulated, they must be implemented.

Step 8: Evaluate results

The final step in the strategic management process is evaluating results. 


\section{Swot Analysis}

SWOT analysis or environmental analysis is to identify an organization's strengths, weaknesses, opportunities, and threats. The purpose of SWOT analysis is to capture the information from the investigation to the key persons in the organization. The results of SWOT analysis show that what an entity can and cannot do, for environment factors both internal and external (Investopedia, 2018).

As noted by Rue \& Byars (2000, p.151) SWOT analysis composes of the first four letters:

- $\mathrm{S} \quad$ : Strengths (Internal environment factors)

- W : Weaknesses (Internal environment factors)

- O : Opportunities (External environment factors)

- $\mathrm{T} \quad$ : Threats (External environment factors)

A major advantage of using a SWOT analysis is that it provides a general overview of an organization's strategic situation.

\section{Generating Strategies by Using a TOWS Matrix}

SWOT analysis uses to assess organization' $s$ situation and generate a number of possible alternative strategies as well. The TOWS Matrix or reversal of SWOT illustrates how to external opportunities and threats facing a particular corporation can be matched with that company's internal strengths and weaknesses to result in four sets of possible strategic alternatives. It can be used to generate corporate and business strategies. Generating a series of possible strategies for the company or business unit is under consideration based on particular combinations of the four sets of factors: (Wheelen \& Hunger, 2012, p.230)

SO strategies : the strategies of using strengths to gain advantage from opportunities.

ST strategies : the strategies of using strengths to avoid threats.

WO strategies: the strategies of taking advantage from opportunities to overcome weaknesses.

WT strategies : the strategies of minimizing weaknesses and avoid threats.

\section{RESEARCH METODOLOGY}

\section{Population and Sample}

1. The population used in this research consisted of 125 students of the Faculty of Management Science, Thepsatri Rajabhat University.

2. The samples, selected by purposive sampling, were 35 students in the same class, who enrolled in strategic management course that the researcher was responsible for teaching in the $2^{\text {nd }}$ semester of the academic year 2017 . 


\section{Experimental Model}

Experimental model was a one - group pretest - posttest design as shown in Table 1.

TABLE 1: One-Group Pretest-Posttest Design

\begin{tabular}{llc}
\hline \multicolumn{1}{c}{ Pretest } & \multicolumn{1}{c}{ Test } & Posttest \\
\hline & \multicolumn{1}{c}{$\mathrm{X}$} & $\mathrm{T}_{2}$ \\
\hline & & \\
$\mathrm{X}$ & stand for teaching using skill workbook & \\
$\mathrm{T}_{1}$ & stand for pretest scores & \\
$\mathrm{T}_{2}$ & stand for posttest scores &
\end{tabular}

\section{Research Instruments}

Research instruments adopted in this study included:

1. A skill workbook on environmental analysis and generating strategies.

2. 20 items of achievement test with five multiple choices.

Steps of constructing and finding the quality of the research instruments:

1. The constructing and finding the quality of research instruments were as follows:

1.1 Analyze problems of teaching strategic management course in classroom.

1.2 Study the content of the environmental analysis and generating strategies.

1.3 Study the guidelines to develop the skill workbook.

1.4 Study documents and research papers relating to content of the environment analysis and generating strategies.

1.5 Develop the skill workbook on the environmental analysis and generating strategies.

1.6 Propose the developed skill workbook to experts for revise and evaluate, then modify it based on experts' suggestion.

1.7 Tried out the skill workbook to determine the efficiency of the process and the results. The experimental procedures were as follows:

1.7.1 The first test: Small group testing, one to one experiment (three students by selecting a good, a medium and a weak student each). The result of the experiment had $E_{1} / E_{2}$ equal to $73.38 / 71.57$, which had not yet reached the standard criterion of $80 / 80$. Therefore the skill workbook needed to be improved again.

1.7.2 The second test: Subgroup testing, three to three experiment (nine students by selecting three good, three medium and three weak students each).

The result of $E_{1} / E_{2}$ test was 78.32/77.21, which did not meet the criterion of 80/80.

1.7.3 The third test: Field testing, using 30 students of Faculty of Management Science enrolling in strategic management course to study the suitability of the skill workbook. The result of $E_{1} / E_{2}$ test was 83.84/81.32, which was higher than the standard criterion of $80 / 80$, so it can be applied to the sample.

2. The steps of development and evaluation of the quality of achievement test were as follows: 
2.1 Study theories and methods to develop the achievement test and to evaluate textbooks.

2.2 Analyze the content of skill workbook on the environmental analysis and generating strategies.

2.3 Define the content, learning objectives that need to be measured.

2.4 Develop 20 items of achievement tests with 5 multiple choice.

2.5 The achievement test was proposed to experts to revise and evaluate.

2.6 The modified achievement test was applied to test 30 non - sample students to determine its difficulty and discriminative power. The results of this test had the difficulty value of 0.38 -0.72 , which was in the range of $0.20-0.80$ and the discriminative power was between 0.48 -0.78 , which is in the range of $0.20-1.00$ (Litcharoon, 2011). The achievement test, using Kuder - Richardson's formula, had a reliability of 0.876 , so it can be used for the research.

\section{Data Collection}

Data collection methods were as follows:

1. The achievement test was used as the pretest for 35 students.

2. After 35 students had studied using the skill workbook on the environment analysis and generating strategies, then the same achievement test was used as the posttest for them after the learning for comparison the students' learning achievement before and after by using the skill workbook.

\section{Data Analysis}

Data were analyzed in term of percentage, mean, standard deviation and t-test (paired t-test): descriptive statistics used for testing the efficiency of the skill workbook compared to the standard criterion of $80 / 80(\%)$; inferential statistics used for comparison the students' learning achievement before and after using the skill workbook on environmental analysis and generating strategies.

\section{THE RESULTS OF RESEARCH}

The results of the research were as follows:

Part 1: Shows the efficiency of the skill workbook versus the criterion standard of $80 / 80$ as shown in Table 2.

TABLE 2: The Efficiency of Skill Workbook Versus Criterion 80/80

\begin{tabular}{cccc}
\hline $\begin{array}{c}\text { Skill Workbook on } \\
\text { the Environmental } \\
\text { Analysis and } \\
\text { Generating }\end{array}$ & $\begin{array}{c}\text { In class test } \\
\text { scores }\end{array}$ & $\mathbf{E}_{\mathbf{1}} / \mathbf{E}_{\mathbf{2}}$ \\
Strategies & $\mathbf{E}_{\mathbf{1}}(\boldsymbol{\%})$ & $\begin{array}{c}\text { Posttest scores } \\
\mathbf{E}_{\mathbf{2}}(\boldsymbol{\%})\end{array}$ & \\
\hline & 83.84 & 81.32 & $83.84 / 81.32$ \\
\hline
\end{tabular}


Table 2 reveals that the skill workbook had the efficiency of 83.84/81.32, which was higher than the standard criterion of $80 / 80$. That is, the students'knowledge related to strategic management course attained by using the skill workbook was improved.

Part 2: Shows the results of the comparison of the students' learning achievement before and after using the skill workbook as shown in Table 3.

TABLE 3: The Comparison of Students' Learning Achievement before and after Using the Skill Workbook

\begin{tabular}{lcccccc}
\hline \multicolumn{1}{c}{ Test } & $\begin{array}{c}\text { Full } \\
\text { Scores }\end{array}$ & N & M & S.D. & t & Sig \\
\hline Pretest & 20 & 35 & 8.37 & 1.62 & $32.01 *$ & .000 \\
\hline Posttest & 20 & 35 & 16.31 & 1.41 & & \\
\hline & & & & &
\end{tabular}

Table 3 reveals that the students'posttest mean score $\quad(M=16.31$, S.D. $=1.41)$ was higher than pretest mean score $(M=8.37$, S.D. $=1.62)$. That is to say, learning achievement after using the skill workbook was higher than before using it at the $\mathrm{p} \leq .05$ level, which accorded with the hypothesis.

\section{DISCUSSIONS}

The findings could be discussed as follows:

1. The results of testing skill workbook on the environmental analysis and generating strategies revealed that students' mean score from doing activities during classroom instruction was 83.84, which was higher than the standard criteria of 80 and also their mean score after using skill workbook was 81.32 , which was higher than the standard criteria of 80 . This could be summarized that the skill workbook had the efficiency of $E_{1} / E_{2}=83.84 / 81.32$ The finding is in the line with the previous studies on the development of the skill workbook (Pholharn, 2006; Phumiwatthana, 2008; Chumkasien, 2008; Jirachaisuthikul, 2008; Tueaktao, 2009; Lawthongkul, 2011) that the skill workbooks were shown to have the efficiency of $80 / 80$. The reasons why the skill workbook on the environmental analysis and generating strategies had the efficiency of 83.84/81.32, might be that the researcher thoroughly studied the steps of a method related to developing the skill workbook from many secondary sources of previous studies as well as sequenced its contents according to its difficulty. After that, the researcher proposed the skill workbook to experts to seek advice and then improve it upon their recommendations. The result is consistent with the recommendation of Sunthornprasert (2001) that the steps of developing the skill workbook should be as follows: 1) analyzing problems from the causes of learning activities by studying through objectives of learning and observation of unwanted behavior of students, 2) studying the details of the course to analyze 
the content, purpose and activities, 3) considering the problem solving approach in item 1 with the skill workbook, by choosing what topic to do and how to use it and how many skill workbooks should be developed, 4) designing many styles of the interesting skill workbook, 5) developing each skill workbook with the test before and after class, 6) proposing skill workbook to expert to revise, 7) trying out it and recording the results for improvement, 8) improving skill workbook using different samples until its standard criterion yield the value of $80 / 80$, and 9) having it published as a manual to explain the use of it.

Finally, the content of the skill workbook on the environmental analysis and generating strategies was examined by the field testing, it found that $E_{1} / E_{2}$ was $83.84 / 81.32$, which was higher than the standard criterion of $80 / 80$. It showed that the efficiency of skill workbook met the standard criterion.

2. The students' learning achievement after using the skill workbook on the environmental analysis and generating strategies developed by researcher were higher than that before using it $(\mathrm{p} \leq .05)$. It showed that when students studied the content course of the environmental analysis and generating strategies using the skill workbook, they got more knowledge and experiences. The result of the mean score was higher than that before using it. The reason might be that students were taught based on the individual differences: providing the thinking process of learning, organizing activities to learners to draw from authentic experience, drilling in skill workbook to complete mastery, enabling learners to think critically, and acquiring the reading habit and continuous thirst for knowledge. This is why the students' learning achievement after using skill workbook was higher than that before using it ( $\mathrm{p} \leq .05)$. The finding is in the line with the previous studies of many researchers: Chetphan (2006) developed the skill workbook on English for communication for the sophomore vocation students which showed that the students' learning achievement after using skill workbook was higher than that before using it ( $\mathrm{p} \leq .05)$; Nambuanoi (2009) developed the skill workbook on the comparison of reading skills and attitude towards learning English between the instruction using skill workbook and conventional teaching which showed that the students' learning achievement of students taught using the skill workbook was higher than those taught using conventional teaching ( $\mathrm{p} \leq 0.05$ ); and also Chumkasien (2008) developed the skill workbook on calculating dilution for grade 10 students which showed that the students' learning achievement after using skill workbook was higher than that before using it ( $\mathrm{p} \leq .05$ ).

\section{CONCLUSION}

On the basis of descriptive and inferential statistics, the findings are considered relevant and noting. It is concluded that, first, the skill workbook on the environmental analysis and generating strategies had the efficiency of 83.84/81.32, which was higher than the standard criterion of 80/80. Second, the students'learning achievement after using the skill workbook on the environmental analysis and generating strategies was higher than that before using it $(\mathrm{p} \leq .05)$. 


\section{RECOMMENDATIONS}

\section{General Recommendations}

On the basis of the descriptive and the inferential statistics, the findings are considered relevant and worth noting; researcher would like to recommend teachers to prepare the lesson plans for the future studies as follows :

1. Teachers who use skill workbook should prepare various ways by studying the details of the skill workbook, including the content of the subject, the purpose of the learning, the teacher's instructions etc.

2. Teachers should use the developed skill workbook along with classroom activities.

3. Teachers should record students' learning behaviors, activities, problems, and obstacles encountered by learners while teaching and learning to improve the instruction.

4. All teachers should pay attention to develop or improve the skill workbook to use in teaching, because it can develop the potential of learners to meet the full potential of learning.

\section{Further Study Recommendations}

The findings of this study may be generalizable to other contexts. Thus future studies can be conducted on the following topics:

1. The skill workbook or instructional packages on other topics in management strategic course should be developed in order to motivate students to take more interest in this subject.

2. Other instructional media should be developed in accordance with the instructional content of strategic management course to improve the quality of learning-teaching process.

3. Classroom research should be conducted continuously to improve learning outcomes or instructional outcomes by using problems encountered in classroom.

4. Classroom research should be conducted with in various instructional models and then compared its instructional outcomes or learning outcomes.

5. The teacher should compare the students' learning achievement of two - group students between conventional teaching and the instruction using skill workbook. 


\section{REFERENCES}

Chumkasien, P. (2008). The development of skill workbook on calculating dilution for grade10 students. Copy.

Dess, G. G. \& Miller, A. (1993). Strategic management. New York: McGraw-Hill.

Investopedia. (2018). SWOT analysis. Retrieved April 15, 2018 from https://www.investopedia.com/terms/s/swot.asp

Jirachaisuthikul, W. (2008). The development of mathematical skill training on an introduction to calculus for grade 12 students. Copy.

Litcharoon, P. (2011). Methodology of social science ( $5^{\text {th }}$ ed.). Bangkok: House of Commerce.

Macfarlane, M. (1984). Reading workbooks: Teacher beliefs and usage. Master's thesis, University of Saskatchewan. Retrieved September 1 , 2018 From https://ecommons.usask.ca/bitstream/handle/1

Marcus, A.A. (2011). Management strategy: Achieving sustained competitive advantage ( $2^{\text {nd }}$ ed.). Singapore: McGraw-Hill.

Minzberg, H. \& Quinn, J., B. (1991). The strategic process: Concepts, contexts, cases. New York: Prentice- Hall.

Nambuanoi, S. (2009). The comparison of reading skill and attitude towards English between using skill workbook and using normal reading for grade 12 students. Master's thesis, Thepsatri Rajabhat University.

Office of the National Education Commission. (1999). Thai Educational Act of B.E. 2542 (1999) and Amendments: Second National Educational Act of B.E. 2545 (2002). Retrieved April 7, 2018, from http://www.onec.go.th.

Pholharn, P. (2006). The development of skill workbook on the skill training of the principle of Thai language for grade 12 students. Master's thesis. UdonThani Rajabhat University.

Phumiwatthana, B.(2008).The Efficiency of skill training on introduction to accountant, Profession and technology strand group, business course. Lop Buri: KhokKratiem Withayalai School.

Pearce, J. A. \& Robinson, R.B. (2013). Strategic management: Planning for domestic \& global competition. (13 ${ }^{\text {rd }}$ ed.). Singapore: McGraw-Hill.

Robbins, S.P. \& Coulter, M. (2002). Management ( $5^{\text {th }}$ ed. $)$. New Jersey: Pearson Education.

Rouse, M. (2018). SWOT analysis. Retrieved March 10, 2018 fromhttps: //searchcio.techtarget.com

Rue, L.W. \& Byars, L. L. (2000). Management ( $8^{\text {th }}$ ed.). New York: McGraw-Hill..

Sunthornprasert, S. (2001). Learning innovation. Chai Nat: Community Development of Law Club.

Thompson, A. A. \& Strickland, A. (1999). Strategic management: Concepts and cases( $11^{\text {th }}$ ed.). Boston: McGraw-Hill.

Tueakthao, P. (2009). The use of supplementary reader entitled money and accountant with saving and investment for grade 12 students. Lop Buri: Pibul Withayalai School.

Wheelen, T. L. \& Hunger, J.D. (2012). Strategic management and business policy (13 ${ }^{\text {rd }}$ ed.). Upper Saddle River, New Jersey: Pearson Education. 
